\title{
HCCI combustion - a challenge for internal combustion engine
}

\begin{abstract}
HCCI engine offers a high thermal efficiency combined with low nitrogen oxides and particulate matter emissions. However the key problem: controlled autoignition (CAI) on which is focused this paper is still not solved. Attempts to solve CAI problem as: variable compression ratio (VCR), variable valve train (VVT), exhaust gas recirculation (EGR) and application of fuels having different volatility characteristics and sensitivity to autoignition are disused. Also possibility of fuelling HCCI engine with natural gas (and ignition improver) is presented.
\end{abstract}

Key words: CAI, efficiency, emissions

\section{Spalanie jednorodnego ładunku wywołane samozapłonem wskutek sprężania - wyzwanie dla silników spalinowych}

\begin{abstract}
Silnik o zapłonie samoczynnym zasilany homogeniczna mieszanka (HCCI) oferuje wysoka sprawność przy małej emisji tlenków azotu i cząstek stałych. Jednakże główny problem, jakim jest kontrolowany samozapłon, nie jest jeszcze rozwiązany. Na tym problemie skupia się niniejszy artykut. Omówiono metody rozwiązania problemu kontrolowanego samozapłonu, takie jak: zmienny stopień sprężania, recyrkulacja gazów wylotowych, zmienne fazy rozrzadu oraz zastosowanie jednocześnie dwu paliw o różnej lotności i skłonności do samozapłonu. Przedstawiono także możliwość zasilania silnika HCCI gazem naturalnym (CNG) przy jednoczesnym udziale składników ułatwiających samozapłon.

Słowa kluczowe: kontrolowany samozapłon, sprawność, emisja
\end{abstract}

\section{Introduction}

Homogeneous charge compression ignition (HCCI) engine is one of the most promising engine technologies, which combines the best features of SI and CI engines resulting in low $\mathrm{NO}_{\mathrm{x}}$ and $\mathrm{PM}$ emissions along-side with high efficiency. Despite a lot of work on HCCI engine, its operational range is limited due to difficulties with controlled autoignition (CAI) of homogeneous mixture.

HCCI engine is fueled with homogeneous mixture, autoignition takes place is the whole volume of the combustion chamber when the temperature rise due to compression reaches higher value than auto-ignition temperature $\left(\sim 1200^{\circ} \mathrm{C}\right)$ and when residence time of the mixture is longer than ignition time lag $(\sim 3 \mathrm{~ms})$ [1], there is no flame front, thanks to that nitrogen oxides are reduced and gaseous mixture burns smokeless. Combustion is rapid and localized near TDC, what results in high efficiency, comparable to that of diesel engine, especially, when the engine is fueled with poor mixture. However, implementation of the HCCI process in real engine depends on solving the key problem: controlled autoignition.

The history of HCCI engine began from the moment, when Onishi and co-workers published the basic paper on new combustion process in heat engines, called ATAC Active Thermo-Atmosphere Combustion [2]. This process depends on heating fuel and air mixed together, what results in faster combustion, better efficiency and lower emission. It was very attractive for two-stroke engines, thanks to very fast combustion and low $\mathrm{NO}_{x}$ emission.

The system of thermal activation of the mixture was adapted in several other experimental applications to

\section{Wprowadzenie}

Silnik typu HCCI (Homogenous Charge Compression Ignition - zapłon samoczynny mieszanki jednorodnej) wiąże się z najbardziej obiecującą współcześnie techniką silnikową, łączącą najlepsze cechy silników o zapłonie iskrowym i samoczynnym i zapewniającą małą emisję $\mathrm{NO}_{x}$ i PM oraz wysoką sprawność. Pomimo wielu prac nad silnikiem HCCI, jego zakres pracy jest nadal ograniczony z uwagi na trudności z kontrolowanym samozapłonem (CAI - Controlled Autoignition) mieszanki jednorodnej, którą jest zasilany. Samozapłon następuje w całej objętości komory spalania, gdy temperatura ładunku spowodowana sprężaniem osiągnie wartość wyższą od temperatury samozapłonu (ok. $1200^{\circ} \mathrm{C}$ ) oraz gdy czas przebywania mieszanki jest dłuższy niż okres opóźnienia zapłonu (ok. $3 \mathrm{~ms}$ ) [1]. Nie występuje tu front płomienia, dzięki czemu zmniejszona jest emisja $\mathrm{NO}_{x}$, a mieszanina palna w stanie gazowym spala się bezdymnie. Proces spalania przebiega szybko i odbywa się przy położeniu tłoka blisko GMP, co skutkuje wysoką sprawnością (porównywalną do sprawności silników o zapłonie samoczynnym), szczególnie przy zasilaniu mieszanką ubogą. Zastosowanie systemu HCCI w rzeczywistym silniku zależy jednak od rozwiązania kluczowego problemu, jakim jest kontrolowany samozapłon.

Historia silnika HCCI rozpoczęła się wtedy, gdy Onishi ze współpracownikami opublikowali referat na temat nowego typu procesu spalania w silnikach cieplnych, nazwanego ATAC (Active Thermo-Atmosphere Combustion) [2]. Proces ten polega na ogrzewaniu wymieszanego paliwa i powietrza, co powoduje szybsze spalanie, wyższą sprawność i mniejszą emisję. Jest on bardzo korzystny dla silników dwusuwowych, z uwagi na szybkie spalanie i małą emisję $\mathrm{NO}_{x}$. 
two-stroke engines, as IAPAC ${ }^{1)}[3,4]$, AVL-DMI ${ }^{2}$ [5] and Orbital Engine Company - $\mathrm{OCP}^{3)}[6]$ etc. Also the author of this paper applied thermal activation of mixture in order to burn lean mixture [7]. This activities were analyzed in [8]. These and other not mentioned works gave a base, on which HCCI engine is being developed. Homogeneous Charge Compression Ignition (HCCI) process known also as Controlled Auto-Ignition (CAI), may be applied in any combustion engine Fig. 1.

Research and development work on HCCI engine combustion, emissions, controlled autoignition (CAI) and application to real engine is performed in many research automotive centers, e.g. in USA (GM, Ford, Cummins), Germany (Mercrdes-Benz, Volkswagen, Opel), Japan (Nissan) and academic R\&D centers all over the world.

There are two different trends to evaluate so called HCCI engine. The first one is based on SI engine and developed by General Motors and the second one based on CI engine - developed by Mercedes-Benz and Volkswagen [9]. Contemporary HCCI engines don't work in whole range of load and speed according to HCCI process.
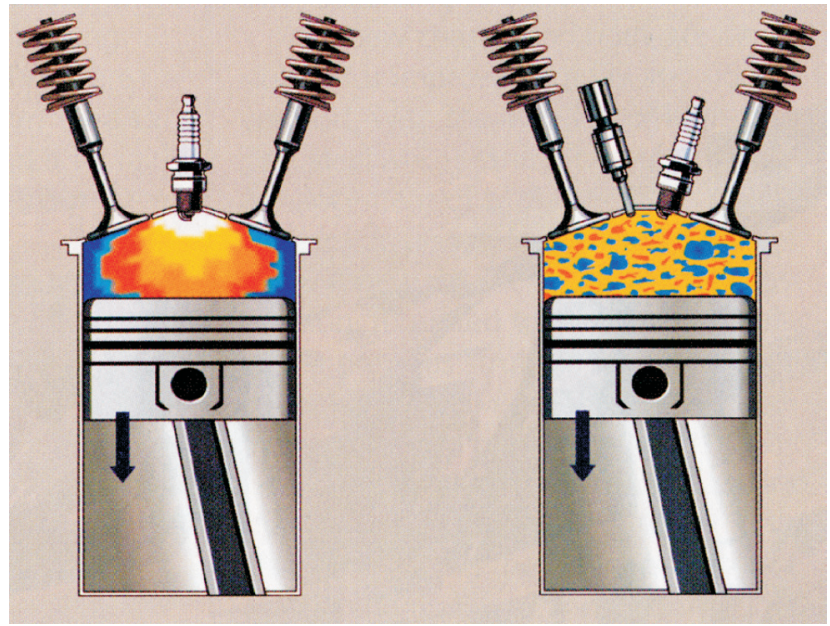

Fig. 1. Comparison of combustion processes in SI engine and HCCI engine [9]

Rys. 1. Porównanie procesów spalania w silniku ZI i HCCI [9]

General Motors provided the first public presentation of automobiles driven by HCCI engines: a Saturn Aura (Fig. 2) and Opel Vectra equipped with $2.2 \mathrm{dm}^{3}$ Ecotec four cylinder engines [9]. Both engines are fuelled with gasoline (or bioethanol) injected directly into the cylinders and have lower compression ratio (CR) than CI engines. The fuel sensor, like in flex-fuel engines, enables application of different fuels, like gasoline and ethanol.

The second approach, represented by Volkswagen and Mercedes-Benz [9] is based rather on CI engine than SI gasoline. Example of this trend is realised in Volkswagen 2.0-L14 HCCI engine and Mercedes-Benz 1.8 L DiesOtto engine applied to hybrid electric assist motor of Mercedes-

\footnotetext{
1) Injection Assistée par Air Comprimeé

2) Direct Mixture Injection

3) Orbital Combustion Process
}

System termicznej aktywacji mieszaniny palnej zastosowano również w kilku innych rozwiązaniach eksperymentalnych silników dwusuwowych, takich jak IAPAC [3, 4], AVL-DMI [5], OCP [6] i innych. Również autor niniejszego artykułu wykorzystywał termiczną aktywację mieszaniny palnej przy spalaniu ubogich mieszanek [7]. Analizę tych prac przedstawiono $\mathrm{w}$ [8]. Wyżej wymienione prace, wraz z innymi, o których tu nie wspomniano, były podstawą rozwoju silnika HCCI. Proces zapłonu samoczynnego mieszanki jednorodnej (HCCI), znany również jako kontrolowany samozapłon (CAI), może być zastosowany w dowolnym silniku spalinowym (rys. 1).

Prace badawczo-rozwojowe nad procesem spalania, emisją szkodliwych składników spalin i kontrolowanym samozapłonem w systemie HCCI oraz aplikacją systemu w rzeczywistym silniku są prowadzone $\mathrm{w}$ wielu ośrodkach badawczych, np. w USA (GM, Ford, Cummins), w Niemczech (Mercedes-Benz, Volkswagen, Opel), w Japonii (Nissan) oraz ośrodkach akademickich na całym świecie.

Można wskazać na dwa główne kierunki rozwoju systemu HCCI. Pierwszy opiera się na silniku o ZI i został opracowany przez koncern General Motors. Drugi opiera się na silniku ZS i został opracowany przez firmy Mercedes-Benz i Volkswagen [9]. Współczesne silniki HCCI nie zapewniają pracy w systemie HCCI w pełnym zakresie obciążeń i prędkości obrotowych.

Koncern General Motors jako pierwszy publicznie zaprezentował samochody z silnikami HCCI. Były to Saturn Aura (rys. 2) oraz Opel Vectra z czterocylindrowym silnikiem Ecotec o pojemności skokowej 2,2 $\mathrm{dm}^{3}$. Oba silniki zasilane są benzyną (lub alkoholem etylowym) w systemie wtrysku bezpośredniego i charakteryzują się niższym niż silniki ZS stopniem sprężania. Czujnik składu paliwa, taki jak w pojazdach FFV, umożliwia zastosowanie różnych paliw, jak benzyna i alkohol etylowy.

Drugi kierunek rozwoju silników HCCI, realizowany przez firmy Volkswagen i Mercedes-Benz [9], opiera się w większym stopniu na rozwiązaniach silnika ZS niż silnika ZI. Przykładem jest silnik Volkswagen 2,0-L14 HCCI oraz Mercedes-Benz 1,8 L DiesOtto zastosowany w układzie hybrydowym z pomocniczym silnikiem elektrycznym w samochodzie koncepcyjnym Mercedes-Benz F700 (rys. 3), przedstawionym na wystawie Frankfurt Auto Show w 2007 r. Czterocylindrowy silnik z dwustopniowym układem turbodoładowania zasilany jest $\mathrm{w}$ systemie wtrysku bezpośredniego i kontrolowanego samozapłonu. $\mathrm{W}$ rozwiązaniach firmy VW stosuje się opóźnienie otwarcia zaworu doprowadzającego recyrkulowane gorące gazy spalinowe do sterowania momentem samozapłonu ładunku, co wymaga bardzo szybkiego i dokładnego sterowania zaworami, oraz pomiar ciśnienia w poprzednich cyklach pracy silnika do regulacji parametrów następnych cykli.

Opracowany przez firmę Volkswagena silnik z systemem spalania HCCI zasilany jest paliwem syntetycznym o specjalnych właściwościach. Hybrydowy układ napędowy firmy Mercedes-Benz składa się z silnika HCCI pracującego w optymalnych warunkach (stałe obciążenie i prędkość ob- 


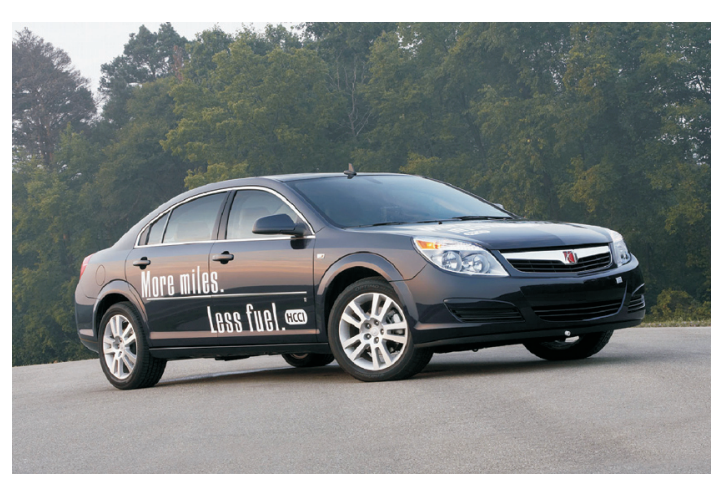

Fig. 2. GM Saturn Aura HCCI demonstration car [9] Rys. Samochód demonstracyjny GM Saturn Aura HCCI [9]

Benz F700 concept car, shown at the 2007 Frankfurt Auto Show (Fig. 3). It is direct injection, four cylinder engine with two-stage turbocharging and controlled auto-ignition. VW Company uses retardation of recirculated hot gases to control charge auto-ignition and the pressure monitoring of the preceding cycle to adjust the next one. These processes requires very fast and accurate valve timing.

The Volkswagen's combined combustion system engine is fueled with synthetic fuel of sophisticated features. Mercedes-Benz hybrid drive-train combines HCCI engine working in optimum working conditions (constant speed and load) with electric motor, that provides required torque and speed in wide operational conditions. HCCI engine has direct injection system and is fueled with gasoline.

However, contemporary authentic HCCI engines can operate only in strictly defined speed and load conditions.

Intensive work is now focused on extension of the area of homogeneous mixture compression ignition process in wide range of speed and load. This target may by reached with application of sophisticated methods and special fuels. This problem will be discussed below.

\section{Combustion in HCCI engine}

HCCI combustion is dominated by local chemical kinetic reactions. Turbulence has little direct effect on combustion, but may alter temperature distribution and boundary layer thicknes, what results in small temperature differences in the cylinder volume which have considerable effect on combustion, because chemical kinetics is very sensitive to temperature. HCCI is controlled by hydrogen peroxide $\left(\mathrm{H}_{2} \mathrm{O}_{2}\right)$ decomposition [10] which occurs at a temperature range 1050-1100 K. In the case of low octane fuel (e.g. diesel fuel) significant low temperature heat reactions begin at temperature of $800 \mathrm{~K}$, which drive the mixture up to the above mentioned temperature necessary to $\mathrm{H}_{2} \mathrm{O}_{2}$ decomposition and autoignition. However for high octane fuels (e.g. gasoline), little heat is released prior to main ignition at $1050-1100 \mathrm{~K}$. Chemistry of HCCI autoignition and combustion is identical to the chemistry of knock in SI engines. Above facts show, that HCCI is sensitive to the type of fuel. rotowa) oraz silnika elektrycznego, który pracuje w szerokim zakresie prędkości i momentu obrotowego. Silnik HCCI zasilany jest benzyną w systemie wtrysku bezpośredniego.

Współczesne silniki w rzeczywistości HCCI mogą pracować tylko $\mathrm{w}$ dokładnie określonym zakresie prędkości obrotowej i obciążenia. Intensywne prace są obecnie prowadzone nad rozszerzeniem zakresu obciążeń i prędkości obrotowych możliwych do uzyskania podczas pracy silnika w trybie zapłonu samoczynnego mieszanki jednorodnej. Cel ten może być osiągnięty przy wykorzystaniu zaawansowanych metod i specjalnych paliw. Zagadnienie to będzie przedstawione $\mathrm{w}$ dalszej części artykułu.

\section{Spalanie w silniku HCCI}

Spalanie w systemie HCCI zależy głównie od kinetyki lokalnych reakcji chemicznych. Turbulencja ma niewielki bezpośredni wpływ na przebieg spalania, ale może zmieniać rozkład temperatury i grubość warstwy przyściennej. Powoduje to występowanie różnic temperatury w objętości cylindra, które mają znaczny wpływ na proces spalania, ponieważ kinetyka reakcji chemicznych zdecydowanie zależy od temperatury. Realizacja procesu HCCI zależy od rozkładu nadtlenku wodoru $\left(\mathrm{H}_{2} \mathrm{O}_{2}\right)$ [10], który następuje w temperaturze1050-1100 K. W przypadku paliw o małej liczbie oktanowej (np. olej napędowy) intensywne niskotemperaturowe reakcje cieplne rozpoczynają się przy temperaturze około $800 \mathrm{~K}$, powodując wzrost temperatury mieszanki do wspomnianej wcześniej wartości, niezbędnej do rozkładu $\mathrm{H}_{2} \mathrm{O}_{2}$ i samozapłonu paliwa. W przypadku paliw o wysokiej liczbie oktanowej wydziela się niewiele ciepła przed samozapłonem w zakresie temperatur 1050-1100 K. Świadczy to o tym, że proces HCCI jest czuły na rodzaj paliwa.

\section{Metody sterowania samozapłonem}

\subsection{Adaptacja silnika do procesu HCCI}

Największym wyzwaniem wobec silników HCCI jest sterowanie zapłonu i spalania w szerokim zakresie warunków eksploatacyjnych, typowych dla silników samochodowych. Badanych i rozwijanych jest kilka potencjalnych metod, z których większość polega na sterowaniu procesami cieplnymi, m.in. na zmianie temperatury ładunku na początku suwu sprężania. Inne metody polegają na zmianie składu mieszanki paliwowej, charakteryzującej się różną lotnością, liczbą oktanową i zawartością dodatków. Pierwszy rodzaj metod stosowany jest w silnikach o ZI, natomiast drugi w silnikach o ZS. 


\section{Autoignition control methods}

\subsection{Engine adaptation to HCCI process}

The biggest challenge to HCCI engines is ignition and combustion control over the wide range of operating conditions typical for automotive engine applications. Several potential methods are being tested and developed. Most of these methods depend sensu stricto - on thermal management: changing temperature of the charge at the beginning of compression stroke. Other methods depend on instantaneous change of the composition of fuel blends, having different volatility characteristics, octane rating and additives. The first type, of the methods are applied to SI engine type, the second to diesel one.

\section{Thermal control, EGR}

This method depends on controlling the temperature, pressure and charge composition at the beginning of compression stroke by EGR application (external or internal) or air compressed by turbocharger [11].

\section{Variable compression ratio (VCR)}

This method depends on controlling $\mathrm{CR}$ in order to adjust inlet charge temperature necessary for autoignition according to fuel type having different octane number $(\mathrm{ON})$. Several technical means of transient changing CR contemporary exist. VCR system is capable to control ignition timing for maintain optional combustion in a wide range of operational parameters.

\section{Variable valve timing (VVT)}

This method depend on changing trapped amount of charge resulting in changing $\mathrm{CR}$ and, in consequence, its temperature. VVT achieves a similar effect as VCR: it can adjust inlet charge temperature for ignition of a variety of fuel types. However VVT controls also composition of the charge thanks to retaining residual gases in the cylinder [12].

The application of EGR and/or variable valve timing is considered to be the most prospective to control CAI.

Effects of EGR on CAI process was investigated in [11]. There are the following effects of hot EGR:

- heating effect of the inlet charge, especially for high octane fuels to promote auto-ignition

- dilution effect of the charge: burnet gases replace air resulting in reduction of air-fuel ratio

- heat capacity effect, due to higher specific heat of $\mathrm{CO}_{2}$ and $\mathrm{H}_{2} \mathrm{O}$ contained in burnt gases

- chemical effect, due to promoting auto-ignition of fresh mixture.

In the case of isothermal EGR cumulative effect is as follows: auto-ignition is retarded (mainly due to predominant heat capacity effect), combustion is slower, heat release rate and $\mathrm{NO}_{\mathrm{x}}$ emission are lower. In the case of hot EGR autoignition is advanced and combustion duration is shortened (but excessive EGR decelerate combustion). Auto-ignition is controlled by charge heating effect, but combustion duration is dominated by dilution and heat capacity effect. EGR (hot and isothermal) may be external, controlled by ECU, or internal by variable valve timing $[13,14]$.

Summing up: hot EGR controls auto-ignition timing by charge heating effect and combustion duration by dilution effect and capacity effect. The use of recycled hot burnt gases

\section{Regulacja cieplna, EGR}

Metoda ta polega na regulowaniu temperatury, ciśnienia i składu ładunku na początku suwu sprężania przez zastosowanie recyrkulacji spalin (zewnętrznej lub wewnętrznej) lub powietrza sprężanego przez turbosprężarkę.

\section{Zmienny stopień sprężania (VCR)}

Metoda ta polega na regulowaniu stopnia sprężania w celu uzyskania temperatury ładunku niezbędnej do jego samozapłonu, w zależności od typu paliwa i jego liczby oktanowej. Istnieje kilka sposobów realizacji zmiennego stopnia sprężania. System VCR pozwala na sterowanie chwilą samozapłonu, aby zapewnić prawidłowe spalanie w szerokim zakresie parametrów operacyjnych silnika.

\section{Zmienne fazy rozrządu (VVT)}

Metoda ta polega na zmianie ilości ładunku w cylindrze i w rezultacie jego ciśnienia i temperatury. Przy zastosowaniu VVT uzyskuje się podobne efekty jak przy VCR - możliwe jest regulowanie temperatury ładunku w celu wywołania samozapłonu różnego typu paliw. VVT pozwala również na regulację składu ladunku przez zatrzymanie reszty spalin w cylindrze.

Zastosowanie EGR i VVT jest uważane za najbardziej perspektywiczny sposób sterowania CAI.

Badania wpływu EGR na proces CAI zostały opisane w pracy [11]. Stwierdzono, że ,gorący” EGR powoduje:

- efekt ogrzewania świeżego ładunku, co w szczególności w przypadku paliw wysokooktanowych ułatwia ich samozapłon

- efekt rozcieńczania ładunku - spaliny zajmują miejsce powietrza i zmniejsza się współczynnik nadmiaru powietrza - efekt zmiany pojemności cieplnej, z uwagi na wyższe ciepło właściwe obecnych w spalinach $\mathrm{CO}_{2} \mathrm{i}_{2} \mathrm{O}$

- efekt chemiczny, z uwagi na ułatwienie samozapłonu świeżej mieszanki.

W przypadku izotermicznego EGR ostatecznym skutkiem jest opóźniony samozapłon (głównie z powodu dominującego wpływu pojemności cieplnej), wolniejsze spalanie, mniejsza szybkość wywiązywania ciepła i mniejsza emisja $\mathrm{NO}_{\mathrm{x}}$. W przypadku ,gorącego" EGR samozapłon ulega przyspieszeniu, a czas spalania ulega skróceniu (nadmierny EGR spowalnia jednak przebieg spalania). Samozapłon zależy od efektu ogrzewania świeżego ładunku, natomiast czas spalania w głównej mierze zależy od rozcieńczenia ładunku i jego pojemności cieplnej. EGR („gorący” i izotermiczny) może być zewnętrzny, sterowany przez ECU, lub wewnętrzny uzyskiwany za pomocą zmiennych faz rozrządu $[13,14]$.

Podsumowując: ,gorący” EGR umożliwia regulowanie chwili samozapłonu przez wpływ na ogrzewanie ładunku oraz regulowanie czasu spalania przez rozcieńczenie i zmianę pojemności cieplnej ładunku. Zastosowanie gorących gazów spalinowych wydaje się najbardziej skutecznym sposobem kontrolowania samozapłonu. Strategia związana ze zmiennymi fazami rozrządu polega na zatrzymaniu pewnej części spalin w cylindrze przez wcześniejsze zamkniecie zaworu wylotowego (tzw. ujemne przekrycie zaworów), przy wykorzystaniu elektrohydraulicznego napędu zaworów lub mechanicznego układu zmiennych faz rozrządu [12]. Opóźnione otwarcie zaworu dolotowego (IVO) i wczesne 
seems to be the most effective means to control auto-ignition. The strategy of valve timing depends on trapping residual gas by early exhaust valve closing, known as negative valve overlap, with the use of electrohydraulic valve actuation system or mechanical variable camshaft timing system [12]. Retarded inlet valve opening (IVO) and early exhaust valve closing (EVC) results in faster mixing of burnt and fresh gases, more homogeneous mixture and uniform temperature distribution. Retarded inlet valve closing (IVC) reduces effective CR and also retards auto-ignition. Schematic of the controlled auto-ignition in the HCCI engine based on SI engine is shown in Fig. 4.

\subsection{Mixture of fuels having different volatility characteristics}

In HCCI engines, auto-ignition and the rate of combustion are mainly controlled by the fuel chemical kinetics [15]. Therefore fuel volatility characteristics plays a main role in CAI process. When CAI process in diesel type engine is considered, fuels having high cetane (and low octane) number should be applied. Not all fuels having high $\mathrm{CN}$, such as diesel oil, may by applied to HCCI engine, because their volatility is low and homogeneous mixture cannot be formed. High volatility high $\mathrm{CN}$ fuels prone to autoignition, e.g. toluene $(\mathrm{CN}=56$, as diesel fuel) may by used to promote CAI in HCCI engine [16]. On the other hand, in order to avoid very high heat release rate fuels retarding combustion should be used. These two fuels (parent fuel), constitute a blend of an appropriate proportion. These fuels, having different volatility characteristics according to the combustion phasing, control auto-ignition and combustion. E.g. in [16] diesel oil surrogate for CAI control under HCCI engine conditions consisted with 50\% n-heptane and 50\% toluene. Also other experiments showed, that ignition delay and burning rate can be independently controlled using different fuel mixtures [17]. Study on primary reference fuels showed that:

- with decreased $\mathrm{ON}$ (increased $\mathrm{CN}$ ) of the fuel auto-ignition advances, peak heat released increases and combustion duration gets longer

- low ON fuel can operate at low load and high ON - at high load.

Instead of parent fuel mixing, they may by injected separately by the use of separate fuel systems or sequentially by two-stage injection [18]. The first method demands an extra injection system. Port fuel injection provides a premixed charge in the cylinder and pilot direct injection fuel (having high $\mathrm{CN}$ ) controls the ignition and combustion of premixed (homogeneous) mixture. The second method depends on two-stage injection of over mentioned fuels, gives good results and don't require additional injection system [19]. Schematic of the controlled auto-ignition in HCCI engine based on CI engine is shown in Fig. 5.

\section{Application of natural gas to HCCI engine}

Natural gas is applied to combustion engine as an alternative fuel. Due to low CN, CI engines should be converted to spark ignition or to dual fuel system. Diesel fuel plays a zamknięcie zaworu wylotowego (EVC) powoduje szybsze mieszanie spalin i świeżego ładunku, większą homogeniczność mieszanki oraz ujednolica rozkład temperatury. Opóźnione zamknięcie zaworu dolotowego (IVC) zmniejsza efektywny stopień sprężania oraz opóźnia wystąpienie samozapłonu. Schemat kontrolowanego samozapłonu w silniku HCCI opartym na silniku o ZI przedstawiono na rys. 4.

\subsection{Mieszanina paliw o różnej lotności}

W silnikach HCCI samozapłon i szybkość spalania zależą głównie od kinetyki spalania paliwa [15], stad też charakterystyka lotności paliwa odgrywa główną rolę $\mathrm{w}$ procesie CAI. Biorąc pod uwagę proces CAI w silnikach o ZS, należy stosować paliwa o wysokiej liczbie cetanowej (niskiej liczbie oktanowej). Nie wszystkie jednak paliwa o wysokiej liczbie cetanowej, na przykład olej napędowy, mogą być używane w silnikach HCCI, ponieważ ich niska lotność utrudnia utworzenie homogenicznej mieszanki. Paliwa o wysokiej lotności i wysokiej liczbie cetanowej, a więc skłonne do samozapłonu, np. toluen (liczba cetanowa 56*, tak jak olej napędowy) mogą być stosowane do ułatwienia CAI w silnikach HCCI [16]. Natomiast w celu uniknięcia bardzo dużych szybkości wywiązywania się ciepła powinny być stosowane paliwa opóźniające spalanie. Stosuje się więc mieszaninę dwu paliw (paliw wyjściowych) o odpowiedniej proporcji składników. Paliwa składowe, o różnej charakterystyce lotności, pozwalają na sterowanie przebiegiem samozapłonu i spalania. Na przykład opisane w pracy [16] paliwo, stosowane zamiast oleju napędowego do sterowania CAI w silniku HCCI, składało się z 50\% n-heptanu i 50\% toluenu. Także inne eksperymenty wykazały, że opóźnienie zapłonu i szybkość spalania mogą być niezależnie sterowane przy zastosowaniu różnych mieszanin paliw [17].

Badania nad głównymi paliwami wzorcowymi wykazały, że:

- ze spadkiem liczby oktanowej (wzrostem liczby cetanowej) paliwa samozapłon następuje wcześniej, wzrasta maksimum wywiązanego ciepła, a czas spalania wydłuża się

- paliwa o niskiej liczbie oktanowej mogą być stosowane przy niskim obciążeniu, a paliwa o wysokiej licznie oktanowej przy wysokim obciążeniu.

Zamiast stosowania mieszanin paliw wyjściowych, oba paliwa mogą być wtryskiwane oddzielnie przy wykorzystaniu oddzielnych układów zasilania lub sekwencyjnie w systemie wtrysku dwufazowego [18]. Pierwsza metoda wymaga zastosowania dodatkowego układu zasilania. Układ wtrysku pośredniego dostarcza do cylindra wstępnie wymieszany ładunek, a bezpośredni wtrysk pilotujący paliwa o wysokiej liczbie cetanowej steruje zapłonem i spalaniem wymieszanej, homogenicznej mieszanki. Metoda druga polega na dwufazowym wtrysku wspomnianych paliw, zapewnia dobre wyniki i nie wymaga dodatkowego układu wtryskowego. Schemat kontrolowanego samozapłonu w silniku HCCI opartym na silniku o ZS przedstawiono na rys. 5.

\footnotetext{
*W rzeczywistości toluen ma bardzo małą liczbę cetanową, LOB toluenu wynosi 115 (przyp. tłum.)
} 


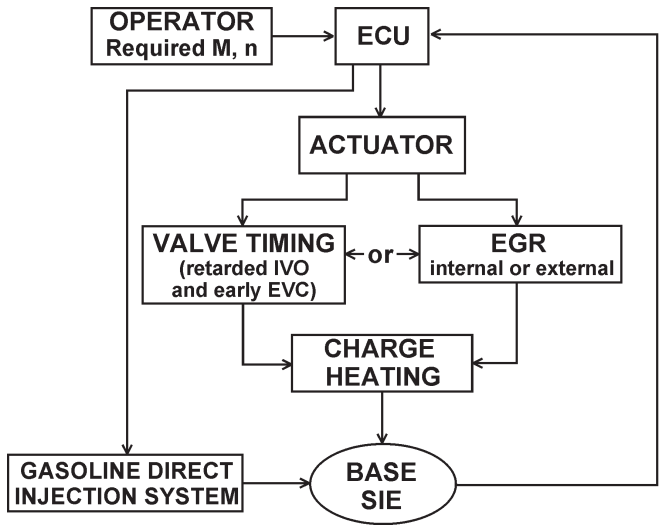

Fig. 4. Controlled auto-ignition in the HCCI engine based on SI engine (SIE). Closed loop control system Rys. 4. Kontrolowany samozapłon w silniku HCCI opartym na silniku o ZI. System sterowania ze sprzężeniem zwrotnym

role of ignition fuel and NG as main fuel. From dual fuelling of CI engine there is only one step to HCCI system, which was discussed in the last subchapter. Ignition fuel (or ignition improver) may be chosen from a variety of fuels: diesel fuel, hydrogen, DME etc. Hydrogen has high diffusivity thanks to that forms easly homogeneous mixture, at the temperature $>600^{\circ} \mathrm{C}$ explodes spontaneously and improves autoignition of the charge at the desired moment controlled by hydrogen content the mixture. In the experiments described in [20] hydrogen was obtained in reforming process of NG with the use of exhaust gas (REGR-process). Addition of hydrogen (up to $15 \%$ ) to NG lowers its auto-ignition temperature and facilitate charge ignition. Due to hydrogen content in the charge, stable operation of HCCI engine was obtained. Instantaneous change of hydrogen fraction is the potential possibility of the control of the moment of auto-ignition.

Another possibility of the enhancement of auto-ignition of NG is addition of dimethyl ester (DME) to NG. Due to high cetane number and high volatility, DME added to NG can ensure successful auto-ignition and combustion [21].

Influence of DME on combustion is as follows:

- majority of DME combustion is consumed before the majority of oxidation of $\mathrm{NG}$

- as DME fraction increases, the low temperature heat release of DME becomes significant and drives auto-ignition of the charge

- as NG fraction increases, the operating range of the engine becomes lower and the engine is unstable in the range of $\lambda<2$.

Also as in the case of hydrogen, changing instantaneously DME content in the inlet charge, is the possible potential way to control auto-ignition in HCCI engine.

\section{Conclusions}

From above analysis the following results may be drawn:

1. HCCI engine yet is not in the phase of mass production. Even only few demonstration cars driven with "HCCI engine" were shown at motor-shows.

\section{Zastosowanie gazu ziemnego $\mathrm{w}$ silnikach HCCI}

Gaz ziemny jest alternatywnym paliwem do silników spalinowych. Z uwagi na niską liczbę cetanową gazu ziemnego, silniki o zapłonie samoczynnym muszą być adaptowane do tego paliwa przez zastosowanie zapłonu iskrowego lub zasilania dwupaliwowego (dualfuel). W systemie tym głównym paliwem jest gaz ziemny, natomiast wtryskiwany olej napędowy stanowi źródło zapłonu. System dual-fuel jest bardzo podobny do systemu HCCI opisywanego w poprzednim rozdziale. Paliwo powodujące samozapłon (albo dodatek poprawiający zdolność do samozapłonu) może być wybrane spośród różnych paliw, takich jak: olej napędowy, wodór, eter dimetylowy itd. Wodór charakteryzuje się wysokim współczynnikiem dyfuzji, dzięki czemu łato tworzy mieszanki homogeniczne. W temperaturze powyżej $600^{\circ} \mathrm{C}$ samorzutnie wybucha, przez co ułatwia samozapłon ładunku w wymaganym momencie, zależnym od zawartości wodoru w mieszance. W badaniach opisanych w pracy [20] wodór był otrzymywany w procesie reformingu gazu ziemnego z wykorzystaniem spalin (proces REGR). Dodatek wodoru (do 15\%) do gazu ziemnego obniża temperaturę jego samozapłonu i ułatwia zapłon ładunku. Dzięki obecności wodoru w ładunku uzyskano stabilną pracę silnika HCCI. Szybka zmiana ilości wodoru w ładunku umożliwia potencjalnie sterowanie momentem samozapłonu mieszanki.

Innym rozwiązaniem poprawiającym zdolność gazu ziemnego do samozapłonu jest dodatek eteru dimetylowego (DME). Wysoka liczba cetanowa i lotność DME zapewniają właściwy samozapłon i spalanie mieszanki.

Można wskazać następujące właściwości DME w procesie spalania:

- spalanie DME wyprzedza spalanie gazu ziemnego

- jeżeli zawartość DME wzrasta, to niskotemperaturowe wywiązywanie ciepła staje się na tyle intensywne, że prowadzi do samozapłonu ładunku

- jeżeli wzrasta zawartość gazu ziemnego, to zakres pracy silnika zawęża się i silnik pracuje niestabilnie przy $\lambda<2$.

Podobnie jak w przypadku wodoru, również szybkie regulowanie zawartości DME w świeżym ładunku umożliwia potencjalnie sterowanie momentem samozapłonu mieszanki w silniku HCCI.

\section{Wnioski}

Na podstawie przeprowadzonej analizy sformułowano następujące wnioski:

1. Silniki HCCI nie są jeszcze produkowane masowo. Jedynie kilka samochodów demonstracyjnych wyposażonych 
2. $\mathrm{HCCI} / \mathrm{CAI}$ process is well realized in the stable conditions of engine operation.

3. Auto-ignition of the charge has a potential to be accomplished/controlled by:

- trapping of the exhaust gas in the cylinder with the use of negative valve overlap

- variable compression ratio

- exhaust gas recirculation

- special composition of the fuel

- addition an ignition improver to the inlet charge.

4. Intensive work is being carried out on CAI process, which is a key problem of HCCI engine development and application.

Artykut recenzowany w silniki HCCI zostało zaprezentowanych na wystawach samochodowych.

2. Proces HCCI/CAI jest poprawnie realizowany w ustabilizowanych warunkach pracy silnika.

3. Samozapłon ładunku może być potencjalnie uzyskany lub sterowany przez:

- zatrzymanie części spalin w cylindrze przy ujemnym przekryciu zaworów

- zmienny stopień sprężania

- recyrkulację spalin

- specjalny skład paliwa

- dodatek do świeżego ładunku substancji ułatwiających zapłon.

4. Prowadzone są intensywne prace badawcze nad procesem CAI, który ma istotne znaczenie z punktu widzenia rozwoju i zastosowania silników HCCI.

\section{Bibliography/Literatura}

[1] Mehresh et al.: Combustion timing in HCCI engines determined by ion-sensor: Experimental and kinetic modelling, Proceedings of the Combustion Institute vol. 30 (2005).

[2] Onishi S. et al.: Active thermo-atmosphere combustion (ATAC) - a new combustion process for internal combustion engines, SAE Paper 790501, 1979.

[3] Durret P. et al.: A new two-strokes engine with compressedair assisted fuel injection for high efficiency low emission applications, SAE Paper 880176, 1988.

[4] Durret P., Moreau J.F.: Reduction of pollutant emissions of the IAPAC two-stroke engine with compressed air assisted fuel injection, SAE Paper 900801, 1990.

[5] Landfahrer K. et al.: Thermodynamic analysis and optimization of two-stroke engine - The flagship concept, SAE Paper 900802, 1990.

[6] Kenny R.G.: Development in two-strokes engine exhaust emissions, Proc. IMechE Part D: Journal of Automobile Engineering, 2006, No. D2, 1992.

[7] Kowalewicz A.: Lean-burn engine - potential analysis, International Journal of Automotive Technology, vol. 2, No 4, 2001.

[8] Kowalewicz A.: Wybrane zagadnienia samochodowych silników spalinowych, Wydawnictwo Politechniki Radomskiej, Radom 2002.

[9] Carney D.: Internal combustion: the next generation SAE International, Automotive Engineering, March 2008.

[10] Homogeneous Charge Compression Ignition (HCCI) Technology. A. Report to the U.S. Congress, Aprill 2001.

[11]Zhao H., Xie H., Peng Z.: Effect of recycled burned gases on homogeneous charge compression ignition engine, Combustion Science and Technology, vol. 177, 2006.

[12] Cao L., Zhao H., Jiang X., Kalin N.: Understanding the influence of valve timing on controlled autoignition combustion, Proc IMechE, vol. 219, Part D: J. Automobile Engineering.

[13]Liü X.C., Chen W., Huang Z.: A fundamental study on the control of the HCCI combustion and emissions by fuel design concept combined with controllable EGR. Part 1: The basic characteristics of HCCI combustion. Fuel, vol. 84 (2005).
[14] Liü X.C., Chen W., Huang Z.: A fundamental study on the control of the HCCI combustion and emissions by fuel design concept combined with controllable EGR. Part 2: Effect of operating conditions and EGR on HCCI combustion. Fuel, vol. 84 (2005).

[15] Tanaka S., Ayala F., Keck J.C., Heywood J.B.: Two-storage ignition in $\mathrm{HCCI}$ engine combustion by fuels and additives, Combustion and Flame, vol. 32 (2003).

[16] Hernandez J.J., Sanz-Argent J., Benajes J., Molina S.: Selection of diesel surrogate for the prediction of auto-ignition under HCCI engines conditions, Fuel, vol. 87, 2008.

[17] Yao M., Zhang B., Chen Z.: Experimental study on homogeneous charge compression ignition combustion with primary reference fuel. Combustion Science and Technology, vol. 179, 2007.

[18] US Patent Inssud on April 30, 2002: Method for controlling compression ignition combustion.

[19] Kim D.S., Kim M.Y., Lee C.S.: Combustion and emission characteristics of a partial homogeneous charge compression ignition engine when using two-stage injection, Combustion Science and Technology, vol. 179, 2007.

[20] Yap D., Peucheret S.M., Megaritis A., Wyszyński M.L., Xu H.: Natural gas HCCI engine operation with exhaust gas fuel reforming, International Journal of Hydrogen Energy, vol. 31, 2006.

[21] Kong S-C.: A study of natural gas/DME combustion on HCCI engine using CFD with detailed chemical kinetics, Fuel, vol. 86, 2007.

Prof. Andrzej Kowalewicz, DSc., DEng.- Professor in the Mechanical Engineering Faculty at Radom University of Technology.

Prof. dr hab. inż. Andrzej Kowalewicz - profesor na Wydziale Mechanicznym Politechniki Radomskiej.

e-mail: andrzej.kowalewicz@pr.radom.pl 